\title{
RIGORÓZNÍ ŘíZENÍ WOLFGANGA WOLFRAMA VON WOLMAR. PŘíSPĚVEK K DĚJINÁM STUDIA POLITICKÝCH PROMINENTU゚*
}

\author{
JANA RATAJOVÁ
}

\author{
RIGOROSUM PROCEDURE OF WOLFGANG WOLFRAM VON WOLMAR \\ CONTRIBUTION TO THE HISTORY OF STUDIES OF PERSONS IN HIGH POLITICAL OFFICE
}

This article explains the circumstances under which Wolfgang Wolfram von Wolmar, a prominent representative of the Nazi regime, received a doctorate at the German University in Prague. The rigorosum proceedings were nonstandard not only due to their subject's political engagement but also because von Wolmar had never attended the German University Prague and his dissertation theses consisted of an already completed book on the history of the Prague University (Prag und das Reich. 600 Jahre Kampf deutscher Studenten), which failed to meet some of the basic requirements placed on a doctoral thesis. The article includes an edition of a substantial part of the rigorosum thesis.

Keywords: Nazism - Protectorate Bohemia and Moravia - German University in Prague - Wolfgang Wolfram von Wolmar

DOI: $10.14712 / 23365730.2018 .28$

V říjnu 1942 zažádal o započetí rigorózního ř́zení na Filozofické fakultě Německé Karlovy univerzity ${ }^{1}$ velmi prominentní student. Byl to Wolfgang Wolfram von Wolmar, v té době vedoucí tiskového oddělení Úřadu říšského protektora. Už samotné započetí rigorózního řízení bylo všechno jiné než standardní: Wolfram von Wolmar zažádal o uznání svého k vydání připraveného spisu Prag und das Reich. 600 Jahre Kampf deutscher Studenten jako disertace př́mo rektora Alfreda Buntrua, ten pak předal žádost (spolu s obtahy připravované knihy) děkanovi filozofické fakulty k dalšímu jednání.

Tehdy dvaatřicetiletý von Wolmar na pražské německé univerzitě nikdy nestudoval. Jako předběžné studium, které mu mělo být započteno do potřebných odstudovaných semestrů, uváděl studium na pražské německé technice (Deutsche technische Hochschule) na počátku trricátých let a čtyři semestry studia na berlínské vysoké škole politické (Deutsche Hochschule für Politik) v letech 1936-1938, které byly zakončeny diplomem. Pražská německá univerzita byla již od roku 1939 plně integrována do sítě ríšských univerzit, takže uznání berlínského studia nepředstavovalo větší problém. Přesto žadatel předkládající disertaci na škole, kde nestrávil jediný semestr, byl $\mathrm{v}$ této době výjimkou (rigorózní rád požadoval minimálně dva semestry odstudované na Německé Karlově univerzitě).

* Př́spěvek vznikl v rámci projektu PROGRES Q23 (Dějiny univerzitní vědy a vzdělanosti).

1 Oficiální název instituce byl v letech 1939-1945 Deutsche Karls-Universität (Prag). 
Von Wolmarova žádost o rigorózní řizení byla akcí čistě politickou (pomineme-li prestiž doktorského titulu) a vázala se prrímo k tématu předkládané práce, jejíž podtitul zněl 600 Jahre Kampf deutscher Studenten a jejíž tištěná verze (předkládané obtahy se bohužel nezachovaly) vyšla roku 1943 v Drážd’anech. Jedná se o nechvalně proslulé vylíčení dějin pražské univerzity z pohledu militantního př́ivržence nacistické a velkoněmecké ideologie, a jak ukáži na posudcích dvou pražských německých historiků, nelze ho vnímat jako typický pohled německý (i když některé linie se v pohledech českoněmeckých historiků na pražské univerzitní dějiny samozrrejmě shodují). Nicméně tento prŕíspěvek nemá být rozborem von Wolmarovy obšírné práce. Jeho cílem je ukázat, jakým zpơsobem se univerzitní instituce a její představitelé postavili k politické objednávce - doktorátu pro vlivného představitele politické moci. Předmětem příspěvku je především to, jaké strategie von Wolmar $\mathrm{v}$ dochovaných psaných textech používá pro vyjádření svého postavení (o ústních jednáních bohužel informováni nejsme), jak se staví k autoritě univerzity (která má pravomoc udělovat žádaný doktorský titul), jakým způsobem a zda vůbec je vyjádřen postoj k profesorům posuzujícím práci, ale také otázka, jak se tito profesoři vyrovnají s posudkem práce politického prominenta, který na jejich univerzitě nikdy nestudoval, navíc nikdy nestudoval historii, a přesto píše dějiny pražské univerzity. Součástí studie je edice části rigorózního spisu, který byl veden Filozofickou fakultou Německé Karlovy univerzity v letech 1942-1943 a je uložen v Archivu Univerzity Karlovy. ${ }^{2}$

Wolfgang Wolfram von Wolmar se narodil 9. června 1910 ve Vídni v rodině důstojníka, ale velkou část dětství a mládí prožil v Československu - základní školu navštěvoval v Liberci, reálku pak začal studovat také v Liberci a pokračoval v Lokti, kde také roku 1928 maturoval. Poté studoval na německé technice v Praze $^{3}$ a zároveň se výrazně angaŽoval v sudetoněmeckém hnutí, byl několikrát zatčen a roku 1934 vyhoštěn. ${ }^{4} \mathrm{~V}$ roce 1938 v Berlíně absolvoval vysokou školu politickou (Deutsche Hochschule für Politik), což byla instituce s velice zajímavým osudem. ${ }^{5}$ Ve zkratce řečeno patřila ve dvacátých letech k velmi progresivním školským zařízením a působila na ní řada význačných osobností (k jejím vyučujícím patřil například pozdější spolkový prezident Theodor Heuss). V roce 1933 velká část pedagogů emigrovala a škola se plně podřídila novému režimu. V jejím čele stál Peter Kleist, který posléze působil na významné pozici na říšském ministerstvu pro obsazená východní území (Reichsministerium für die besetzten Ostgebiete). Podle některých zdrojů bylo na této škole v období nacismu 65 \% vyučujících členy NSDAP, což je zhruba dvoj-

2 Archiv UK (dále AUK), fond Filozofická fakulta Německé univerzity v Praze (dále f. FF NU), Personálie studentů (posudky disertačních prací, absolutoria, přihlášky k rigorózům aj.) - W, Wolfgang Wolfram von Wolmar, k. 88, i. č. 1011.

3 V akademickém roce 1930/1931 studoval chemii (Abteilung Chemie), od dalšího roku do zimního semestru 1933/1934 pak architekturu (Abteilung für Architektur und Hochbau), včetně výuky určené pro budoucí učitele kreslení na stř̌edních školách v akademickém roce 1932/1933 (Abteilung für Architektur und Hochbau, Heranbildung von Lehrkräften für das Freihandzeichnen an Mittelschulen). Archiv ČVUT, fond Německá vysoká škola technická (Deutsche technische Hochschule), Hauptkataloge, 1930/1931-1933/1934.

4 Wolfgang Wolfram von Wolmar měl jen rakouské občanství, vyhoštěn mohl být tedy jako cizinec. K tomu srov. Stanislav Biman, Wolfgang Wolfram von Wolmar. Poznámky k životopisu, in: Jana Čechurová - Pavel Andrš Luboš Velek (edd.), Posláním historik. Pocta prof. Kvačkovi k 80. narozeninám, Praha 2012, s. 420-428.

5 Ke škole srov.: Gideon Botsch, „,Politische Wissenschaft“ im Zweiten Weltkrieg. Die „Deutschen Auslandswissenschaften “ im Einsatz 1940-1945, Paderborn 2006; Ernst HAIGER, Politikwissenschaft und Auslandswissenschaft im „Dritten Reich“ - (Deutsche) Hochschule für Politik 1933-1939 und Auslandswissenschaftliche Fakultät der Berliner Universität 1940-1945, in: Gerhard Göhler - Bodo Zeuner (Hrsg.), Kontinuitäten und Brüche in der deutschen Politikwissenschaft, Baden-Baden 1991, s. 94-136. 
násobek oproti průměru berlínských vysokých škol. Od roku 1939 do konce roku 1943 byl von Wolmar vedoucím tiskového oddělení Úřadu říšského protektora, podléhal mu tedy veškerý legální protektorátní tisk - a von Wolmar svého postavení náležitě využíval, o čemž svědčí mimo jiné i editované zápisy Antonína Fingera z tiskových porad z let 19391941. ${ }^{6}$ Na podzim roku 1943 byl z funkce odvolán a poslán na frontu. Co způsobilo rychlý konec von Wolmarovy kariéry, není úplně zřemé, šetření ohledně údajného nezákonného obohacování během úřední činosti skončilo neurčitě. Stanislav Biman za odvoláním von Wolmara vidí především Sicherheitsdienst (zejména pak v osobě Martina Paula Wolfa), ale vliv obecně přisuzuje i personálním změnám, ke kterým došlo ve vedení pražského gestapa a SD po atentátu na Heydricha, spekuluje také o možném vlivu rozporuplně přijaté disertační práce. ${ }^{7} \mathrm{Na}$ konci války pobýval von Wolmar ve Vídni. Po válce žil nějakou dobu v Rakousku, kde byl zadržen; Československo tehdy neúspěšně žádalo o jeho vydání. ${ }^{8}$ Po propuštění se odstěhoval do Spolkové republiky Německo, kde působil jako novinář a zemřel 2. prosince 1987 v Düsseldorfu. ${ }^{9}$

Základní analýze byl podroben celý von Wolmarův rigorózní spis. Podobné spisy byly zakládány na filozofické fakultě německé univerzity od roku 1909 pro každé započaté rigorózní rízení a mají poměrně ustálenou podobu. Žadatel o rigoróza měl povinnost doložit, že splňuje všechny požadavky, které předepisuje rigorózní řád - předkládal originál maturitního vysvědčení, doklad o vystudování předepsaného počtu semestrů (mohlo jít o absolutoria různých vysokých škol), dále resumé své disertační práce, doklad o zaplacení zkušební taxy, vlastní životopis, v době okupace předkládal žadatel i potvrzení o árijském původu atd. Originální dokumenty (maturitní vysvědčení aj.) byly po ověření, respektive skončení rigorózního řízení žadatelům vraceny, ale do spisu byly naopak během řízení vloženy posudky disertační práce. Wolmarův rigorózní spis je typický v tom, že obsahoval (podle přiloženého soupisu) všechny náležitosti, které mít měl a které pak byly zčásti žadateli vráceny. Netypický je v tom, že obsahuje i korespondenci dokládající nestandardnost tohoto rigorózního řízení, zejména pak dopisy rektora Buntrua, von Wolmarovy dopisy děkanovi filozofické fakulty a zvláštní dodatek k posudku profesora Wostryho.

Jak vypadalo v dané době (1939-1945) řádné rigorózní řízení na filozofické fakultě? Německá univerzita byla k 1. září 1939 formálně přijata do správy Říše, stala se tedy řádnou říšskou univerzitou a vzápětí (roku 1940) byly staré, v jádru ještě rakouské rigorózní řády nahrazeny řády odpovídajícími říšskému standardu. K získání doktorského titulu bylo zapotřebí odevzdat disertační práci vyhovující dobovým vědeckým standardům, po posouzení práce dvěma oponenty ( $\mathrm{z}$ nichž jeden byl zpravidla vedoucím a zadavatelem práce) a přijetí práce (v rigorózním protokolu poznámka ,approbiert“) byl žadatel připuštěn $\mathrm{k}$ jedné oborové zkoušce - rigorózu. To byla novinka, do té doby skládali absolventi po prrijetí práce dvě rigoróza: dvouhodinové oborové a jednohodinové filozofické. Skladba

6 Jakub KonČElí - Barbara KÖPPLOvÁ - Jitka KRYŠPíNOvÁ (edd.), Český tisk pod vládou Wolfganga Wolframa von Wolmara, Praha 2003.

7 S. Biman, Wolfgang Wolfram von Wolmar, s. 427.

8 S. Biman, Wolfgang Wolfram von Wolmar, s. 425, popř. též na <http://mediahub.cz/komentare/900282 -cesti-novinari-ve-stinu-hakoveho-krize-vladce-protektoratniho-tisku-wolfgang-wolfram-von-wolmar -muz-ktery-donutil-ceskeho-novinare-slouzit-risi> (1. 3. 2017).

9 K von Wolmarově poválečné činnosti srov. Susanna Schrafstetter, Siegfried Zoglmann. His Circle of Writers and the Naumann Affair. A nazi Propaganda Operation in Postwar Germany, in: David A. Messenger - Katrin Paehler, A Nazi Past: Recasting German Identity in Postwar Europe, Lexington 2015, s. 113-137. 
oborů byla v rigorózním rádu přesně vymezena. ${ }^{10}$ Jednalo se $\mathrm{v}$ zásadě o dvě oblasti - oblast filozoficko-historickou a oblast filologickou. A vždy se jednalo o dvouobor v taxativně vymezených kombinacích. Von Wolmarovým oborem byly „Landes- und neuere Geschichte, Volkslehre, Nationalitätenkunde" (zemské a novější dějiny, národopis). ${ }^{11}$

Jen na okraj je možné dodat, že ke změnám rigorózních řádů došlo po roce 1939 na všech fakultách německé univerzity, ale nejrychleji se prosadily právě na filozofii a prírodovědě (zřejmě právě pro odstranění jedné rigorózní zkoušky a také kvưli délce studia), naopak na právech, kde k rigorózům přibyla ještě písemná disertační práce (která do té doby nebyla vyžadována), dostudovávala až do roku 1945 celá řada studentů podle starých norem a disertačních prací bylo do zániku univerzity roku 1945 dokončeno minimum.

Z von Wolmarova spisu vyplývá, že nejprve někdy v první polovině ř́ijna 1942 přišel za rektorem Buntruem ${ }^{12} \mathrm{~s}$ př́ním předložit svůj dokončený a $\mathrm{v}$ nakladatelství přijatý spis jako disertační práci. Buntru se obrátil př́mo na děkana filozofické fakulty dopisem, kde tento fakt uvádí. Rektor ve svém dopise v zásadě intervenuje u děkana Hofmanna ${ }^{13}$ ohledně zajištění možnosti doktorátu pro von Wolmara. Toho zde uvádí s plným názvem funkce „Regierungsrat [...] Leiter der Gruppe Presse beim Herrn Reichsprotektor“, aby svou žádost náležitě objasnil. Po jednání s rektorem se, jak vyplývá ze spisu, von Wolmar obrátil př́ímo na děkana Hofmanna a zřejmě mu bylo řečeno (spis odkazuje na proběhlá jednání), jaké doklady má pro započetí rigorózního řízení dodat. Velkou část spisu pak tvoří materiály dodané von Wolmarem spolu s průvodním dopisem. V další korespondenci se řeší, jakým způsobem je možné dostát povinnostem rigorózního řádu. Problémem se ukázalo být to, že žadatel o doktorský titul měl mít minimálně šest započitatelných semestrů, z toho minimálně dva semestry vystudované na pražské univerzitě, ${ }^{14}$ což von Wolmar nesplňoval. Základní specifičností von Wolmarova rrízení je tedy vůbec samo připuštění $\mathrm{k}$ tomuto řízení a také přijetí jeho spisu jako disertační práce.

Pokusme se tedy v zachovaných dokumentech vystopovat, jakých strategií von Wolmar použil, aby byl připuštěn $\mathrm{k}$ rigorózům (je třeba zde připomenout, že $\mathrm{v}$ korespondenci se nacházejí jen letmé zmínky o přímých osobních jednáních tohoto vysokého politického představitele, člena SS a NSDAP, s představiteli univerzity $-\mathrm{s}$ rektorem, s posuzovateli práce a zřejmě i s děkanem).

10 Promotionsordnung für die Philosophische Fakultät der Deutschen Karls-Universität in Prag ... vom 19. Juli 1940, AUK, fond Úřední tisky Německé univerzity v Praze (dále f. ÚT NU), k. 27, i. č. 608.

11 AUK, f. FF NU, Rigorózní protokol, sv. IV, č. 159.

12 Alfred Buntru (1887-1974), odborník na vodní stavby, byl od roku 1939 rektorem německé techniky a do úřadu rektora univerzity byl dosazen na přechodnou dobu, nicméně tento úřad zastával od 1. 4. 1942 do 1. 11. 1943. V této době stál zároveň v čele dvou pražských německých vysokých škol a po jistou dobu i německé zemědělské vysoké školy v Děčíně-Libverdě. Po válce působil jako profesor techniky v Cáchách. K němu a období jeho rektorátu srov. Alena MíšKová, Německá (Karlova) univerzita od Mnichova k 9. květnu 1945, Praha 2002, s. 125-148.

13 Erich Hofmann (1895-1982), lingvista se specializací na baltské jazyky, působil v Praze od roku 1940, děkanem filozofické fakulty byl v akademickém roce 1942/1943, od roku 1943 působil na ř́ršském ministerstvu vědy, výchovy a osvěty (Reichsministerium für Wissenschaft, Erziehung und Volksbildung).

14 „Nur solche Bewerber können zur Promotion zugelassen werden, die mindestens zwei Semester an der Prager Universität studiert haben. In Ausnahmefällen kann mit Zustimmung des Rektors von dieser Voraussetzung abgesehen werden." Promotionsordnung für die Philosophische Fakultät der Deutschen Karls-Universität in Prag ... vom 19. Juli 1940, § 4. AUK, f. ÚT NU, k. 27, i. č. 608. 


\section{Životopis}

Standardní součástí rigorózního spisu je žadatelův životopis, který má být zaměřen na dobu studia a absolvované školy, nicméně jeho součástí bývají také osobní části, často jasně sebepropagačního charakteru. U Wolfganga Wolframa von Wolmar tomu není jinak. Celý životopis je formulován s důrazem na to, jak autor za první Československé republiky trpěl (otec, rakouský důstojník, byl zbaven občanství a neměl práci), jak si musel živobytí opatř̌ovat již od útlého věku sám, jak byl již od mládí politicky správně uvědomělý a byl za to postižen několikerým zatčením. Zajímavou pasáží je i zdůvodnění, proč po maturitě nezačal řádně studovat na univerzitě, která ho lákala, nýbrž na technice. ${ }^{15}$

Toto zdůvodnění je velmi zajímavé, protože čtenářum životopisu (zaměstnancům univerzity) muselo být jasné, že pro von Wolmara jako pro absolventa reálky nebyla cesta na univerzitu uzavřená. Absolventi reálek mohli na univerzitě studovat, ovšem za předpokladu doplnění maturitní zkoušky na gymnaziální úroveň, tedy o řečtinu, latinu a filozofickou propedeutiku. To platilo pro posluchače filozofické fakulty, zatímco např́ílad pro prírodovědu byly dané předpisy zmírňovány a místo dodatečných zkoušek z řečtiny se připouštěly i zkoušky z jiných jazyků. Von Wolmar měl tedy cestu na univerzitu pouze ztíženou, ne uzavřenou, jak tehdy všichni velmi dobře věděli. Také ostatní části životopisu budí přinejmenším pochybnosti, do jaké míry von Wolmar upravoval svůj životopis vyloženými nepravdami či ,jen“ neuváděním podstatných okolností (například proč rodina žila v Československu, když otec ani syn neměli československé občanství).

\section{Členství v politických hnutích, společenská angažovanost}

Jak již bylo mnohokrát napsáno, von Wolmar byl prominentem nacistického režimu a $\mathrm{v}$ dochované korespondenci svou politickou angažovanost častokrát připomíná. V životopise zdůrazňuje trvání politické angažovanosti od mladého věku (zejména angažovanost v Deutsche Studentenschaft a NSD-Studentenbund), svá dosavadní vyznamenání (Hitlerjugend), v dopise děkanovi podtrhuje, že jako prověřený člen SS jistě nemusí dokládat árijský původ (a v dokladech, které předložil, skutečně tento doklad není uveden). Korespondence je vedena na úředním hlavičkovém papíre (,Wolfg. Wolfram von Wolmar Regierungsrat, Leiter der Gruppe Presse beim Reichsprotektor in Böhmen und Mähren") a jeho funkci zdůrazn̆uje i rektor Buntru $\mathrm{v}$ dopise děkanovi. Na několika listech papíru se dozvídáme o politickém významu von Wolmara hned několikrát.

Ze spisu vyplývá, že děkan filozofické fakulty Hofmann nakonec požádal rektora Buntrua oficiálním dopisem z 11. 11. 1942 o plné započtení odstudovaných semestrů von Wolmara a o osvobození od požadavku dvou semestrů absolvovaných na pražské univerzitě. Rektor samozřejmě vyhověl. $\mathrm{V}$ této chvíli již nic nebránilo oficiálnímu započetí rigorózního řízení, o jehož průběhu svědčí zejména dva posudky von Wolmarova spisu od profesorů Wilhelma Wostryho a Antona Ernstbergera.

15 Viz text životopisu v prŕloze. 


\section{Disertační práce}

Rektor s děkanem filozofické fakulty tedy vyřešili problém možného připuštění k rigorózu k von Wolmarově spokojenosti. V cestě $\mathrm{k}$ rigorózním zkouškám ovšem stála ještě jedna závažná překážka: von Wolmarovův spis musel být přijat jako disertační práce se všemi náležitostmi. Nelehký a politicky ožehavý úkol, totiž sepsání posudku, připadl profesorům Wostrymu a Ernstbergerovi. V rukou psaných prípiscích $\mathrm{v}$ korespondenci je vedle těchto jmen uváděn ještě Hans Joachim Beyer, ${ }^{16}$ ale je zřejmé, že on práci neposuzoval.

Sám von Wolmar svou práci charakterizuje v dopise ze 7. listopadu 1942. Zdůrazňuje její politické zadání i schválení pro tisk nejvyššími místy a věnování zesnulému Reinhardu Heydrichovi. ${ }^{17}$ Poukazuje také na to, že se jedná o práci nejen vědeckou, ale také o „Bekenntnisarbeit", která má německému lidu ukázat kulturní výkon (,Kulturleistung“) nejstarší německé univerzity a boj generací jejích studentů za říši a národ (,für Reich und Volk").

Práce je tedy zaštítěna autoritou moci a ideologické správnosti, legitimizační funkci má i připomenutí dedikace knihy zesnulému zastupujícímu říšskému protektorovi. Profesoři požádaní o posudky byli v nelehké pozici, jakákoli kritika mohla být vnímána i jako kritika politických míst, která dílo zaštitují. Na posudcích je zajímavé už to, že každý z profesorů vypracoval zvláštní posudek. $V$ drtivé většině dochovaných príípadů totiž posudek vyhotovoval pouze jeden z profesorů a druhý jen připsal, že s hodnocením kolegy souhlasí, prŕpadně doplnil jenom svůj podpis. Dva posudky jsou zachovány toliko v několika málo prípadech, kdy se hodnocení liši. ${ }^{18}$

V prosinci 1942 předkládá čtyřstránkový posudek profesor historie Wilhelm Wostry. Profesor Wostry (1877-1951) patřil k dlouhodobým profesorům německé univerzity - řádným profesorem československých dějin ${ }^{19}$ byl jmenován roku 1927 (mimořádným 1923). Jeho postoj k nacistickému režimu velmi dobře shrnul Karel Hruza. ${ }^{20}$ Wostry patřil k zastáncům tzv. „Volksforschung“ a nacistický režim velmi rychle přijal, patřil mezi spolupracovníky Heydrichovy nadace a měl se stát autorem plánovaných dějin Čech a Moravy. Přesto ho lze ve srovnání s fanatiky typu Heinze Zatscheka či Hanse Joachima Bayera charakterizovat spíše jako umírněného univerzitního učence. ${ }^{21}$ Wostry kromě posudku přiložil také osobní dopis děkanovi, ve kterém poukazuje na zvláštní okolnosti von Wolmarovy práce a zdůrazňuje, že chtěl předat posudek osobně, ale bohužel se tak nestalo. Samotný posudek

16 Hans Joachim Beyer (1908-1971), působil na filozofické fakultě od roku 1942 a patřil k předním představitelům nacistické vědy na fakultě a $\mathrm{k}$ zakladatelům tzv. Heydrichovy nadace.

17 Srov. príloha.

18 V př́ípadě Wostryho a Erntsbergera je to např. u disertační práce Herberta Schlapky, Der Schutzvereingedanke in den Sudetenländern bis 1894, kdy Wostry hodnotí výborně, Erntsberger velmi dobře. AUK, f. FF NU, Rigorózní spis $\mathrm{k}$ disertační práci sign. V-13.

19 V této době byla jeho profesura přejmenována na dějiny sudetoněmecké, respektive zemské.

20 Karel Hruza, Wilhelm Wostry a Wilhelm Weizsäcker: vzorni mužové, rádní učenci a věrní vlasti synové?, in: Pavel Soukup - František Šmahel, Německá medievistika v českých zemích do roku 1945. Práce z dějin vědy 18 , Praha 2004, s. 305-352. K Wostrymu též Nina LohmanN, Wilhelm Wostry und die ,,sudetendeutsche "Geschichtsschreibung bis 1938, AUC-HUCP 44/1-2, 2004, s. 45-145; TÁž, „Heimat und Volk": der Historiker Wilhelm Wostry zwischen deutschböhmischer und sudetendeutscher Geschichtsschreibung, in: Stefan Albrecht - Jiř́i Malí̌ - alph. Melville, Die „sudetendeutsche Geschichtsschreibung“ 1918-1960: zur Vorgeschichte und Gründung der Historischen Kommission der Sudetenländer, München 2008, s. 127-149. Popř. Ota KonRáD, Dějepisectví, germanistika a slavistika na Německé univerzitě v Praze 1918-1945, Praha 2011, s. 114-117 a zejména $\mathrm{k}$ jeho aktivitám za války s. 257-262.

21 K. Hruza, Wilhelm Wostry a Wilhelm Weizsäcker, s. 350. 
je neobvykle dlouhý. Wostry opět poukazuje na nestandardní charakter práce, která byla dodána již v obtazích pro tisk a zdůrazňuje také její velký rozsah. Nicméně přes zřejmou politickou objednávku je posudek především rozborem von Wolmarova díla jakožto vědeckého textu, a sem směřuje také řada kritických připomínek, byt' je zřejmé, že na výslednou podobu knihy či výsledek rigorózního ř́zení nebudou mít vliv. Wostry zdůrazňuje, že práce má politický charakter, a to zejména v částech věnujících se období, které autor sám prožil. Pro starší období poukazuje zejména na nedostatečnou práci s prameny a literaturou a chybějící poznámkový aparát. Kromě toho, že autor vůbec nepracuje s českou literaturou (což von Wolmar sám zdůvodňuje tím, že práce je zejména o německém studentovi a k tomuto tématu nelze v českých pracích nalézt nic), kritizuje Wostry také nedostatečné zpracování literatury uvedené v soupise literatury. Navíc poukazuje na nesnadnost koncipování takto široce zaměřené práce $\mathrm{v}$ době, kdy existuje minimum př́pravných studií. Wostry se pozastavuje i nad tím, že bylo takovéto téma vůbec zvoleno, a zároveň připomíná, že je to přes ohromný záběr první autorova práce. Ve zkratce řečeno Wostry má s von Wolmarovou prací zásadní problém - a to zejména jakožto s prací vědeckou. ${ }^{22}$ Pro Wostryho není von Wolmar osobou, která by měla o dějinách univerzity psát, byt' to není v posudku takto př́mo řečeno. Zpochybnění vědeckého charakteru práce je $\mathrm{v}$ tomto př́padě zásadní (nedostatečná práce s literaturou a prameny a politický charakter díla jsou pro profesora historie závažným problémem). Oceňuje naopak v podstatě pramennou hodnotu pasáží založených na vlastních autorových zážitcích. Wostry nakonec hodnotí tuto práci jako „,befriedigend“, tedy uspokojivě. ${ }^{23}$

Druhým posuzovatelem von Wolmarovy práce byl Anton Ernstberger (1894-1966), absolvent univerzit v Praze a ve Vídni, jeden z Wostryho žáků, který na univerzitě působil od roku 1932. Roku 1935 se stal nejdř́ive mimořádným, roku 1942 řádným profesorem obecných dějin novověku. ${ }^{24} \mathrm{~V}$ období druhé světové války byl ředitelem historického semináře a patřil k okruhu spolupracovníků již zmíněného Hanse Joachima Beyera, ${ }^{25}$ významně se podílel na činnosti Heydrichovy nadace. ${ }^{26}$ Ernstbergerův posudek je výrazně kratší a zabývá se von Wolmarovou prací jako myšlenkovým celkem. Zejména připomíná, že podtitul by měl být hlavním titulem práce. Ernstbergerův posudek ukazuje ideologickou čistotu díla, jehož předpoklady i závěry jsou zřejmé. Osudy pražské univerzity jsou neoddělitelnou složkou osudu německé říše. Ideologičnost práce není nijak kritizována, přesto lze z Ernstbergerových formulací vycítit určitý opatrný odstup. „Dies erkannt, war die Hauptsache erkannt. Alles andere musste sich diesem beherrschenden Gesichtspunkte unterordnen. “ To je klíčová věta posudku, která poukazuje na podřízení práce předem danému schématu, bez ohledu na výsledky výzkumu. Také Ernstberger si všímá i dalších

22 „In der Durchführung, die darstellende Gewandtheit erkennen lässt, hat der Autor sich in methodischer Hinsicht nicht an das Schema fachwissenschaftlicher Abhandlungen gehalten, die in den beigegebenen Anmerkungen den auf Vorarbeiten sich gründenden Unterbau erkennen lässt.“

23 Známkování u disertačních prací bylo ausgezeichnet - výborně, sehr gut - velmi dobře, gut - dobře, befriedigend - uspokojivě, unbefriedigend - neuspokojivě.

24 K němu O. Konrád, Dějepisectví, germanistika a slavistika, s. 253. Popř. K. Erik Franzen - Helena PeřinovÁ, Biogramme der Mitglieder der Historischen Kommission der Sudetenländer im Gründungsjahr 1954, in: S. Albrecht - J. Malír - R. Melville, Die „sudetendeutsche Geschichtsschreibung“ 1918-1960, s. 228-229.

25 A. MišKovÁ, Německá (Karlova) univerzita, s. 159.

26 Spolu s H. Zatschekem byl ředitelem institutu pro dějiny Čech a Moravy (Landesgeschichtliches Institut für Böhmen und Mähren), srov. např. Deutsche Karls-Universität Prag, Personal- und Vorlesungsverzeichnis, Sommersemester 1944, s. 22. 
formálních nedostatků (zejména práce s literaturou a prameny atd.). Práci hodnotí stupněm ,gut", dobře (třetí stupeň), tedy o stupeň lépe než Wostry.

Pokud si posudky pozorně přečteme, je zřejmé, že oba profesory, vychované v duchu klasického historismu, musela předkládaná práce nesmírně popuzovat, a to i přes jejich sympatie k velkoněmecké ideologii. Odborná historická práce, a tím spíše práce kvalifikační, měla splňovat určité náležitosti, pracovat s náležitou metodologickou výbavou, což von Wolmarova práce nesplňovala. Nicméně ani jeden z posuzovatelů nevyslovil prímo odmítavé stanovisko, ale z textů posudků je zřejmé, že oba měli k práci zásadní odborné výhrady. Výtky jsou vždy důsledně zaobaleny - do neosobních vazeb s konjunktivními tvary sloves, nebo jsou oslabeny tím, že se jen nadhazují jako možné výtky nějakého imaginárního kritika - a hned jsou odmítnuty poukazem na rozsah, zvláštnost („Eigenart“) či dokumentární hodnotu díla, nemožnost opřít se o přípravné studie apod., nebo jsou jen zpochybněny jako málo podstatné a diskutabilní („Das ist und bleibt Beiwerk und berührt die Hauptsache nicht. Streitfragen sind zudem Streitfragen und lassen mehr als nur eine Antwort zu“). Zde nastíněný problém profesorů německé univerzity s posuzováním práce von Wolmara ukazuje jistou hranici, která existovala mezi odborným stylem německých univerzitních vědců (byt' nacionálně orientovaných) a prací vzniklou na politickou objednávku bez náležité vědecké akribie a metodologické výbavy. Přes všechny výhrady, které vznesli (i nevznesli) profesoři filozofické fakulty, byla práce uznána, Wolfgang Wolfram von Wolmar složil rigorózní zkoušku (o jejím průběhu bohužel informováni nejsme, podle rigorózního protokolu byl von Wolmar hodnocen dobře ${ }^{27}$ a byl dne 13. února 1943 promován doktorem filozofie. V téže době byl ustaven výbor pro vydání dějin univerzity v Praze pod vedením Wilhelma Wostryho, jednotlivé dějinné úseky měli zpracovat němečtí univerzitní historikové. K napsání a vydání práce, směřované původně k výročí 1948, však již ze zřejmých př́čin nedošlo. ${ }^{28}$

\section{Přílohy: část rigorózního spisu Wolfganga Wolframa von Wolmar}

\section{Ediční poznámka:}

Dokumenty byly v souladu s obecně přijatými doporučeními pro novověké německé texty transkribovány, tedy přepsány podle dnešních pravopisných zásad. ${ }^{29}$ To se týká především interpunkce a grafické stránky textu (např. psaní ss a $\beta$, psaní velkých/malých písmen, velkých umlautů apod.), modernizačních zásahů však bylo třeba poměrně málo. Fonetická podoba textu je zcela zachována, včetně austriacismů (benü̈zen) a určitých zvláštností (vypuštěné $e$ ve slovech typu besondern). Byl též ponechán spojovník ve slově Tschecho-Slowakei ve von Wolmarově životopisu, byt' její užití je pro dobu před rokem 1938 věcně nesprávné. Zcela zachováno bylo členění do vět a odstavců. Kulaté závorky odpovídají přssně originálu. Běžné textové zkratky nejsou rozepisovány, méně běžné jsou rozepsány pomocí hranatých závorek (f. > f[ür]); nerozepisujeme ani zkratky institucí apod. složené

27 AUK, f. FF NU, Rigorózní protokol sv. IV, č. 159.

28 A. MíšKovÁ, Německá (Karlova) univerzita, s. 15.

29 Ivan ŠŤovíčEK a kol., Zásady vydáváni novověkých historických pramenů z obdobi od počátku 16. století do současnosti, Praha 2002, s. 61. 
z počátečních písmen (SS, NS, HJ), jejichž grafická podoba je př́padně modernizována $(H . J .>H J)$ a méně známé zkratky jsou vysvětleny v poznámkách. Zachováváme podtržení podle originálu, zvýraznění textu formou proložení mezerami ve strojopise je zde zobrazeno tučným řezem. Na drobné autorské korektury není upozorňováno, ale doplnění, škrty a nahrazení slov, jakož i př́íisky jiných osob jsou zaznamenány v poznámkách. Pravděpodobné gramatické chyby v originálu jsou ponechány s upozorněním pomocí značky [!].

Každý text je uvozen drobným záhlavím se základní charakteristikou a datací a dále s informací, zda se jedná o strojopis, nebo rukopis, o rozsahu a také o všech předtištěných částech (hlavičkách) a razítcích.

\section{Příloha 1: Dopis Wolfganga Wolframa von Wolmar děkanovi FF NU žádající o připuštění k promoci, 7.11. 1942}

Strojopis, 3 strany, na první straně předtištěná hlavička: „Regierungsrat Wolfg[ang] Wolfram von Wolmar, SS-Hauptsturmführer, Leiter der Gruppe Presse i[n] d[er] Abt[ei] l[un]g Kulturpolitik beim Reichsprotektor i[n] Böhmen u[nd] Mähren ". Předtištěná datace a adresa: „Prag VII, ..., Sommerbergstr [aße] 64“30 s vepsanou datací „7. 11. 1942“. $\mathrm{Na}$ konci dopisu prezentační razítko děkanátu filozofické fakulty s datem 10. 11. 1942, č. j. 445/42.

An den Dekan der Philosophischen Fakultät der Deutschen Karlsuniversität

Seine Spectabilität Prof. Dr. E. Hofmann

Prag 1

Mozartplatz $1^{31}$

Ich bitte die Philosophische Fakultät der Deutschen Karlsuniversität zu Prag um Zulassung zur Promotion. Als schriftliche Doktorarbeit bitte ich die von mir bereits eingereichte Arbeit „Prag und das Reich. Sechshundert Jahre Kampf deutscher Studenten“ anzuerkennen.

Die Arbeit ist von mir im Herbst 1938 mit Unterstützung des Reichsstudentenführers SS-Brigadeführer Dr. G. A. Scheel ${ }^{32}$ begonnen und im Mai 1942 fertiggestellt worden. Sie soll zu Beginn des Jahres 1943 im Verlag Franz Müller, Dresden, erscheinen. Aus diesem Grunde musste die Arbeit der Reichsschriftumsstelle im Reichsministerium f[ür] Volksaufklärung und Propaganda sowie der Parteiamtlichen Prüfungskommission zum Schutze des NS-Schrifttums vorgelegt werden. Sie ist von beiden Stellen zur Drucklegung freigegeben und von P[arteiamtlicher] P[rüfunsg-]Kom[mission] z[um] Sch[utze] d[es] NS-Schrifttums in die NS-Bibliographie aufgenommen worden. Mit Zustimmung des Reichsführers SS ist

30 Dnešní ulice Milady Horákové v Praze 7.

31 Dnešní náměstí Jana Palacha v Praze 1.

32 Gustav Adolf Scheel (1907-1979), významný představitel nacistického režimu činný v nacistickém studentském hnutí (Nationalsozialistischer Deutscher Studentenbund), člen SA a SS. Roku 1936 jmenován do funkce,,Reichsstudentenführer“. Roku 1939 se v Praze zúčastnil slavnosti převzetí německé univerzity do říšské správy, po válce zatčen a internován, po propuštění působil jako lékař. 
die Arbeit dem „im Kampfe um die Sicherung der historischen Reichslande Böhmen und Mähren gefallenen SS-Obergruppenführer Reinhard Heydrich“"gewidmet.

Die Arbeit soll die deutsche Kulturleistung der ältesten deutschen Universität und ihrer Studenten und die kämpferische Leistung ungezählter deutscher Studentengenerationen Prags für Reich und Volk dem deutschen Volk plastisch vor Augen führen. Sie soll ferner dazu beitragen, der ersten Universität Deutschlands und der ältesten deutschen Technischen Hochschule die ihrer reichen Geschichte entsprechende Stellung im Großdeutschen Reich auch in den Augen der breitesten Öffentlichkeit wiederzugeben. Diese nicht ganz einfache Aufgabenstellung erforderte es, dass die Arbeit nicht nur wissenschaftlich in Stil und Aufbau gehalten sein durfte, sondern eine Bekenntnisarbeit sein musste.

Wenn ich die Fakultät bitte, dies berücksichtigen zu wollen, möchte ich dies nicht tun ohne darauf hinzuweisen, dass ich die Arbeit während der Dauer von fast vier Jahren neben meinem Beruf und neben kriegseinsatzmässiger Arbeit erstellt habe.

Die Herren Professoren Dr. Wilh[elm] Wostry und Dr. Ernstberger haben die Arbeit gelesen. Auf ihre Anregung hin wurden einige Korrekturen vorgenommen.

Als Prüfungsfächer bitte ich Geschichte (alte ${ }^{33}$ und neuere) und Volkslehre und Nationalitätenkunde wählen zu dürfen. ${ }^{34}$

Ich habe in den Semestern von 1930/31 bis zum WS 35 1933/34 an der Deutschen Technischen Hochschule in Prag und im Sommersemester 1935, SS 1936, WS 1936/37 und WS 1937/38 an der Deutschen Hochschule für Politik, Berlin, studiert (Belege sind beigefügt). Ich bitte die Fakultät mir diese Studiensemester anrechnen zu wollen.

Als Beamter des Deutschen Reiches, als Träger des goldenen Ehrenzeichens der HJ und des Ehrenzeichens des NSD-Studentenbundes ${ }^{36}$ sowie als SS-Führer bitte ich von Beibringung der Unterlagen zum Nachweis der arischen Abstammung befreit zu werden, da sich diese Unterlagen zurzeit beim Rasse- und Siedlungshauptamt des RFSS ${ }^{37}$ befinden.

Heil Hitler!

Wolfram von Wolmar ${ }^{38}$

\section{Příloha 2: Životopis Wolfganga Wolframa von Wolmar, 7. 11. 1942}

Strojopis, 3 strany. Na první straně predtištěná hlavička: ,, Wolfg. Wolfram von Wolmar“. Předtištěná datace a adresa: „Prag VII, ..., Sommerbergstr [aße] 68“ s vepsanou datací „,den 7. 11. 1942“. Na konci dopisu prezentační razitko děkanátu filozofické fakulty s datem 10. 11. 1942, ̌́.j. 445/42.

33 Slovo „alte“ škrtnuto a ručně nadepsáno „Landes“ - nejspíš korektura provedená zaměstnancem fakulty.

34 Vlevo marginální př́ípisek rukou (tužkou): „Wostry / Ernstberger / Beyer / Mitte Jänner“ - zřejmě poznámka zaměstnance fakulty se jmény navrhovaných posuzovatelů a termínem vyhotovení posudku.

35 V odstavci užity běžné zkratky pro zimní a letní semestr (WS - Wintersemester, SS - Sommersemester).

36 Nationalsozialistischer Deutscher Studentenbund.

37 Reichsführer SS.

38 Vlastnoruční podpis. Na dalším listu následuje seznam př́iloh (není editován). 


\section{$\underline{\text { Lebenslauf }}$}

Geboren am 9. 6. 1910 in Wien als Sohn des Rittmeisters Alfred Wolfram von Wolmar ${ }^{39}$ und der Wilhelmine geb. Simitsch von Hohenblum.

Schulbildung: 5 Jahre Grundschule in Reichenberg, 7 Klassen Realschule in Reichenberg und Elbogen a[n] d[er] E[ger], Abitur 1930 in Elbogen abgelegt, Anschliessend 8 Semester an der DTH ${ }^{40}$ in Prag und 4 Semester an der Deutschen Hochschule für Politik (Berlin) mit Diplom-Prüfung abgeschlossen.

Ich musste mir bereits als Realschüler während der letzten beiden Schuljahre vor dem Abitur das Geld für die Beendigung des Mittelschulstudiums durch körperliche Arbeit verdienen, da mein Vater (ehem[aliger] Berufsoffizier) von den tschechischen Behörden im Jahre 1923 als staatenlos erklärt worden war und seine Existenz verloren hatte. - Als ich im Jahre 1930 an die DTH nach Prag kam, begann für mich ein besonders schwerer Existenzkampf als Werkstudent. Dessen ungeachtet trat ich noch während meines ersten Studiensemesters in die völkische Arbeit der deutschen Studentenschaft ein.

Im Studium an der DTH fand ich nicht die geringste innere Befriedigung, während mir die Universität infolge meines Realschulabiturs verschlossen war. Ich stellte mich daher umsomehr Arbeitswillen in die politische und studentische Arbeit.

Schon als Realschüler war ich im Jahre 1928 Mitglied des NS-Jugendverbandes geworden. (Die Mitgliedschaft wurde mir später von der HJ angerechnet. Verleihung des goldenen HJ-Ehrenzeichens.)

In der Folgezeit übernahm ich innerhalb der Deutschen Studentenschaft Prag das Amt für politische Schulung. Gleichzeitig wurde ich Mitglied des NSD-Studentenbundes. Wenig später wurde ich durch den damaligen Führer der Sudetendeutschen Studentenschaft Dr. B. Adolf ${ }^{41}$ in die Führung des Kreises IX der D[eutschen] St[tudentenschaft] (Tschecho-Slowakei) als Vertreter des Studentenführers berufen. Nach der Verhaftung des Kreisführers Dr. Adolf übernahm ich in einer schweren Zeit, der Zeit nach der polizeilichen Auflösung des NSD-Studentenbundes und der Deutschen Studentenschaft, die Führung der letzteren für das Gebiet der Tschecho-Slowakei. Die mir gestellte Aufgabe war: die Deutsche Studentenschaft an den vier deutschen Hochschulen in der Tschecho-Slowakei in der illegalen Zeit als völkische Substanz zu erhalten, zu sichern und als aktive Stoßtruppe im nationalsozialistischen Sinne zu erhalten. Es war klar, dass diese meine Arbeit der politischen tschechischen Polizei auf die Dauer nicht verborgen bleiben konnte, zumal ich

39 Podle údajů v katalozích posluchačů německé techniky zemřel Alfred von Wolmar roku 1931 nebo 1932 (studenti uváděli jméno otce či poručníka).

40 Deutsche Technische Hochschule, tj. pražská německá technika.

41 Bernhard Adolf (1908-1977), jeden z představitelů sudetoněmeckého studentského hnutí, absolvent pražské německé právnické fakulty (1935), během druhé světové války v Praze jako jeden z vysokých úředníků nacistické správy, prezident ústředního svazu průmyslu. Po válce vězněn, po propuštění 1956 ve Spolkové republice Německo. Casto zmiňován v souvislosti s pražským působením Hannse Martina Schleyera (jedna z obětí Frakce rudé armády). Srov. Lutz HachmeIster, Schleyer: eine deutsche Geschichte, München 2004, s. 190-199. 
seit der Auflösung der DNSAP 42 als früheres Mitglied derselben und als Ausländer unter besonderer Überwachung stand.

Während des Jahres 1933 wurde ich siebenmal verhaftet. Mann musste mich zwar sechs Mal wieder auf freien Fuß setzen. Nach der 7. Verhaftung wurde ich jedoch nach neuerdings ergebnislos verlaufenen Verhören aus dem Staatsgebiet der ehemaligen Tschecho-Slowakei ausgewiesen. Nach meiner Ankunft in Dresden wurde ich in die Reichsstudentenführung nach Berlin berufen. Im März 1935 berief mich der Leiter der Auslandsorganisation der NSDAP Gauleiter E. W. Bohle ${ }^{43}$ in seine Dienststelle als Gauhauptstellenleiter. In der Stellung war mir die Bearbeitung südosteuropäischer Spezialfragen übertragen. Am 30. Januar 1937 berief mich Reichsminister Dr. Frick ${ }^{44}$ in das Reichsministerium des Innern. Nach der Errichtung des Protektorates wurde ich als Sachkenner in das Amt des Reichsprotektors i[n] $\mathrm{B}$ [öhmen] u[nd] M[ähren] berufen, wo ich gegenwärtig die Stellung des Leiters der Gruppe Presse bekleide.

Ich bin SS-Hauptsturmführer im Reichssicherheitshauptamt (SD) und Angehöriger der NSDAP.

Seit 1937 bin ich verheiratet mit Lieselotte geb. Retzlaff.

Auf Grund freiwilliger Meldung habe ich drei militärische Übungen beim J.R.8, ${ }^{45}$ Frankfurt/Oder geleistet. Militärischer Dienstgrad: Gefreiter d[er] Res[erve] u[nd] Reserve-Offiziers-Anwärter.

Wolfram von Wolmar 46

Prag, am 7. 11. 1942

\section{Př́loha 3: Posudek Wilhelma Wostryho, 12. 12. 1942, s př́ípisem (pro děkana) z 21. 12.1942}

Průvodní př́pis: rukopis na prázdném listu, 1 strana. Posudek: rukopis, 3 strany, na první straně hlavička ve formě razitka: „,Prof. Dr. Wilhelm Wostry Prag XIX., Yorckstraße 10“.47

42 Deutsche Nationalsozialistische Arbeiterpartei, Německá nacionálně socialistická dělnická strana, působící v Československu v letech 1918-1933.

43 Ernst Wilhelm Bohle (1903-1960), jeden z čelných představitelů NSDAP, od roku 1933 v říšském sněmu, od roku 1937 vedoucí zahraniční organizace NSDAP (NSDAP/AO), po válce odsouzený při jednom z následných norimberských procesů.

44 Wilhelm Frick (1877-1946), jeden z čelných představitelů třetí říše. 1933-1943 ministr vnitra (1943 nahrazen Heinrichem Himmlerem), 1943 jmenován Říšským protektorem pro Protektorát Čechy a Morava, 1946 odsouzen při norimberském procesu k trestu smrti.

45 Patrně 8. (Preußisches) Infanterie-Regiment, tedy 8. (Pruský) pěší pluk, sídlící ve Frankfurtu nad Odrou.

46 Vlastnoruční podpis.

47 Dnešní ulice Na Zátorce v Bubenči (Praha 6). 


\section{Euerer Spektabilität}

erlaube ich mir, anbei die Beurteilung der Dissertation des Herrn v[on] Wolmar zu übersenden. Ich habe sie, da es ein außergewöhnlicher Fall ist, eingehender besprochen, denn hier muss das Für und Wider besonders begründet und erwogen sein, da es sich um ein bald im Druck ausgehendes Buch handelt. Es war gedruckt bezw. gesetzt, ehe es als Dissertation eingereicht war.

Ich hatte heute eigentlich vor, Ihnen das Gutachten persönlich zu übergeben u[nd] hatte es zu diesem Zwecke mitgenommen; doch habe ich leider im Verlaufe unserer Unterredung und in dem Bestreben, Sie tunlichst kurz aufzuhalten, das vergessen. So hole ich es postalisch nach und wiederhole meine Weihnachts- und Neujahrswünsche.

Ich verbleibe mit dem deutschen Gruße

Heil Hitler!

Ihr sehr ergebener

Wilhelm Wostry

Prag, 21. XII. 1942

Beurteilung

der als Dissertation vorgelegten Arbeit: Wolfgang Wolfram von Wolmar: Prag und das Reich. 600 Jahre Kampf deutscher Studenten

Die bereits im Drucksatz vorliegende Arbeit fällt in mancher Hinsicht aus dem Rahmen heraus, der sonst bei Dissertationen gewohnt ist. Schon äußerlich durch ihren Umfang: sie umfasst 591 Seiten im Druck. Aber auch durch ihren Gehalt: sie umfasst den ganzen Zeitraum des Bestandes der Prager Karls-Universität und besonders die Jahre und ihre Ereignisse, die der Verfasser als Student und politisch denkend und national handelnd miterlebt hat. Die Arbeit hat dadurch einen stark politischen Einschlag von der Erlebnisseite her. In der Durchführung, die darstellende Gewandtheit erkennen lässt, hat der Autor sich in methodischer Hinsicht nicht an das Schema fachwissenschaftlicher Abhandlungen gehalten, die in den beigegebenen Anmerkungen den auf Vorarbeiten sich gründenden Unterbau erkennen lässt. Für einen solchen Unterbau hätte es auf weiten Strecken des frei gewählten ${ }^{48}$ Themas auch an jeglichem behauenen und vielfach auch noch unbehauenen Materials [!] gefehlt. Denn wie seit Tomeks Geschichtswerk keine größere, umfassende Geschichte der Prager Universität mehr zustande gekommen ist, so gibt es auch keine Geschichte des Studententums an ihr im Ganzen; vielfach fehlt es auch an bereits behandelten Einzelabschnitten aus ihr und meist an allen näheren Vorarbeiten, sei es zu Spezialuntersuchungen, sei es zu einer Gesamtdarstellung.

Die Arbeit unternimmt es also, trotz dieser ungünstigen Vorbedingungen, einen weiten Bogen zu spannen von der Gründung der Universität bis zur jüngster Vergangenheit, also sozusagen bis an die Schwelle der Gegenwart - schon dass der Autor ein solches Unternehmen in Angriff genommen hat, ist positiv zu werten. Allerdings die Weite dieses Bogens

48 Původně napsáno „bearbeiteten“, to pak autorem škrtnuto a nadepsáno ,gewählten“. 
macht es verständlich, dass die Fülle der Probleme, die es umschließt, nicht erschöpfend, ${ }^{49}$ auch nicht immer - und dies gilt besonders von den, die älteren Teile der Universitätsgeschichte betreffen, der Teilen - dem Stande der Forschung entsprechend behandelt werden konnten. Dem aber und den Bedenken, die hier vorgebracht werden können, steht das Verdienst entgegen, dass ${ }^{50}$ hier einmal mit frischem Mute eine sicherlich nicht leicht $\mathrm{zu}$ bewältigende Aufgabe ${ }^{51}$ angefasst worden ist, die eben wegen der vielen Schwierigkeiten, die sie enthält, noch lange unberührt geblieben wäre. Den Mangel an Vorarbeiten muss man sich vor Augen halten, wenn man der Arbeit selbst nicht ungerecht werden will; ebenso wie man bedenken muss, dass man in ihr, trotz ihres so weit ausholenden Themas und trotz der gewandten Form der Darstellung eine wissenschaftliche Erstlingsarbeit vor sich hat. Das Literaturverzeichnis könnte leicht zu der Meinung verführen, (zumal, wie gesagt, auf Anmerkungen mit Literatur- und Quellenangaben verzichtet ist), der Verfasser habe die vorliegende Literatur nicht ausreichend benützt; denn sicher hat er mehr Werke und Arbeiten benützt und zeigt (das ${ }^{52}$ ist dem Kenner nicht allzu schwer zu erkennen) Kenntnisse, die auf weiter reichendes Interesse und auf weitere Verwertung schließen lassen. Dass er die tschechische Literatur nicht herangezogen hat, dürfte sich, abgesehen von anderen Momenten, daraus erklären, dass er nicht erwarten mochte, für den Hauptgegenstand seines Interesses, und das ist der deutsche Student in Prag, gerade in dieser Literatur etwas finden zu können. Gewiss wäre es an sich und zur Einsicht in die Art und den Umfang seiner Literatur- und Quellenbenützung von Vorteil gewesen, wenn die einzelnen zugehörigen Belege aus den Anmerkungen ersichtlich gemacht worden wären. Auch sonst wird mancher Wunsch offen, manche strengere Forderung unerfüllt bleiben und sicherlich ${ }^{53}$ wird sich mancher Einwand machen, manche Ausstellung vorbringen lassen; fachliche Kritik wird an manchem Punkte einsetzen können. Aber es wird doch zuzugeben sein, dass der Verfasser bemüht war, die weiteren Zusammenhänge der einzelnen Ereignisse aufzuzeigen, dass sein warmes Interesse an seinem Thema während des Ablaufs des ganzen Zeitraums, das er überblickt, nicht nachlässt und dass er bestrebt war, auch dort vorwärts zu kommen, wo ein Weg bisher kaum und vielfach gar nicht gebahnt war.

Es ist nicht zu leugnen, dass gegen manche Aufstellung manches sich bemerken liesse, dass manches auf Ablehnung, anderes auf Widerspruch stoßen wird. Es ist aber nicht zu verkennen, dass die Arbeit einen fühlbaren Mangel, ein an Bedürfnis nach einer Geschichte des Prager deutschen Studententums namentlich während der letzten Jahre abzuhelfen bestrebt ist.

Mag so der eine, zeitlich genommen, größere Teil, fachliche Mängel und sachliche Versehen aufweisen, so wird das aufgewogen durch den andern, in der Darstellung größeren, Teil, der die Ereignisse namentlich der letzten bewegten Jahre behandelt. Dieser Teil gewinnt dadurch, dass hier ein unmittelbarer Augenzeuge, oder doch ein, wenn auch nicht unmittelbar Beteiligter, so doch interessiert Mit-erlebender ${ }^{54}$ erzählt, geradezu Quellen-

49 Původně napsáno „,behandelt“, pak autorem škrtnuto.

50 Autor napsal omylem dvakrát za sebou „dass“ na zlomu stran, první poté škrtl.

51 Původně napsáno „Arbeit“, poté škrtnuto a nahrazeno slovem „Aufgabe“.

52 Zde je autorská korektura svědčící o obtížném hledání adekvátní formulace: původně napsáno „benützt (und dass“, to pak přepsáno do finální podoby (slovo „zeigt“ nadepsáno nad rádku).

53 Slova „und sicherlich“ nadepsána dodatečně.

54 Slova „Beteiligter“ a „Mit-erlebender“ původně psána jako adjektiva s malými počátečními písmeny, pak opravena na substantiva s velkými písmeny. 
wert. Es spricht hier ein Vertreter der Studenten ${ }^{55}$ oder doch mit innerster Anteilnahme und innerlicher Beteiligung den Geschehnissen Zusehender; es sprechen aus ihm die Anschauungen und Auffassungen der Prager deutschen Studentenschaft seiner Zeit und die Auswirkungen (auch die politischen) des Zeitgeschehens. Der Verfasser hat, national-politisch interessiert und bewegt, in die Vorgänge jener Jahre geschaut - und gibt wieder, was er geschaut hat. Diese Wiedergabe lässt ein für Dissertationen nicht gewöhnliches Vermögen der Darstellung erkennen; zugleich tritt nicht nur ein durch interessiertes Miterleben der Vorgänge erworbenes Wissen, sondern auch eine gefestete, nationale und politische Überzeugung ${ }^{56}$ zu Tage.

Hält man die positiven und die negativen Momente einander gegenüber, zieht man auch die eingangs erwähnte Eigenart der Arbeit und die besondern Umstände ihrer Entstehung in Betracht, dann dürfte es gerechtfertigt erscheinen, den Kandidaten zu den mündlichen Prüfungen zuzulassen.

Befriedigend

Prag, 12. Dezember 1942

Prof. Dr. Wilhelm Wostry

\section{Př́loha 4: Posudek Antona Ernstbergera, 4. 1. 1943}

Strojopis na prázdných listech bez hlavičky, 2 strany.

\section{Gutachten}

über die Dissertation des Herrn Wolfgang Wolfram von Wolmar „Prag und das Reich. 600 Jahre Kampf deutscher Studenten“

Die Arbeit ging offenbar vom Nebentitel aus „600 Jahre kampf deutscher Studenten“. Dass sie zum Haupttitel „Prag und das Reich“ gelangte, war selbstverständlich. Sie musste dorthin gelangen. Denn es lässt sich keine Geschichte der Prager Universität schreiben und wollte sie sich noch so sehr auf ein Teilgebiet beschränken, ohne dass die grossen Zusammenhänge und die bestimmenden Kräfte des Gesamtgeschens aufgegriffen und mitdargestellt werden müssten, darin als dem grösseren Ganzen der kleinere Teil, Universität, unlösbar verkettet liegt. Das Ganze ist das Schicksal des Deutschtums und des Reiches. Der Teil ist das Schicksal der Prager Universität, der ersten Reichsuniversität. Hier gibt es keine Trennung, die möglich wäre. Jeder Schnitt ginge durch lebendiges Leben. Eins gehört zum andern.

Dies erkannt, war die Hauptsache erkannt. Alles andere ${ }^{57}$ musste sich diesem beherrschenden Gesichtspunkte unterordnen.

55 Slova „der Studenten“ nadepsána dodatečně.

56 Původně napsáno „nationale Beurteilung“, slovo „Beurteilung“ poté škrtnuto a nahrazeno slovem „Überzeugung“, dodatečně připsáno adjektivum ,politische“.

57 Slovo ,andere“ nadepsáno dodatečně rukou. 
$\mathrm{Ob}$ in der Ausführung manche Einzelheit so oder anders lauten könnte, darüber liesse sich rechten. Es begegnet hie und da eine Unklarheit, auch eine Ungenauigkeit, gewiss auch eine Übertreibung, ebenso auch eine oder die andere Wiederholung. Doch wo fände sich das bei einem Werk dieses Ausmasses nicht? Ob ein nebensächlicher Zierat und beigefügter Schnörkel glatt und rund oder weniger glatt und weniger rund gelang, darauf kommt es nicht an. Das ist und bleibt Beiwerk und berührt die Hauptsache nicht. Streitfragen sind zudem Streitfragen und lassen mehr als nur eine Antwort zu.

Dass Begeisterung und Liebe zur Sache mit am Werke waren, wird gerne und offen einbekannt. Sie waren für die Wärme der Darstellung von Vorteil. Die eine oder andere Voreingenommenheit verteilte Licht und Schatten vielleicht nicht ${ }^{58}$ immer so gerecht, wie sie einem tieferen Blicke heute schon erscheinen mögen. Aber auch hier handelt es sich nur um Grad-, nicht Wesenunterschiede.

Eine vollgerechte Nachprüfung und Wertung erschwert der Umstand, dass fast jede unmittelbaren Zitate fehlen, und zwar sowohl für die Originalquellen (Urkunden und Akten) wie für die benützte Literatur. Das beigefügte Schrifttumsverzeichnis lässt jede Möglichkeit offen.

Die Arbeit liegt schon im Drucke vor. Sie ist eine vollwertige Dissertation.

Gesamturteil: gut.

Prag, 4. Januar 1943

Ernstberger ${ }^{59}$

JANA RATAJOVÁ

\title{
Das Rigorosum von Wolfgang Wolfram von Wolmar. Ein Beitrag zur Geschichte des Studiums politischer Prominenter
}

\author{
ZUSAMMENFASSUNG
}

Unser Beitrag erhellt die Umstände, unter denen ein Prominenter des Naziregimes: Wolfgang Wolfram von Wolmar, an der Prager deutschen Universität seinen Doktortitel erwarb. Das Rigorosum war nicht nur aus Gründen des politischen Engagements der betreffenden Person alles andere als standardgemäß, sondern auch deshalb, weil von Wolmar zu keiner Zeit an der Prager Universität studiert hatte und als Doktorarbeit ein bereits zur Veröffentlichung bereitstehendes Buch über die Geschichte der Prager Universität vorlegte (Prag und das Reich. 600 Jahre Kampf deutscher Studenten), das einige grundlegende Forderungen, die an die Qualität einer solchen Arbeit gestellt wurden, nicht erfüllte. Teil unseres Beitrages ist die Edierung wesentlicher Teile der Rigorosenakte.

Deutsche Übersetzung Wolf B. Oerter

Jana Ratajová

Ústav dějin a archiv UK, Praha

Jana.ratajova@ruk.cuni.cz

58 Původně napsáno „nicht vielleicht“, rukopisnou korekturou pak slova prohozena.

59 Vlastnoruční podpis. 